\title{
Assessment of the ecotoxicity of urban estuarine sediment using benthic and pelagic copepod bioassays
}

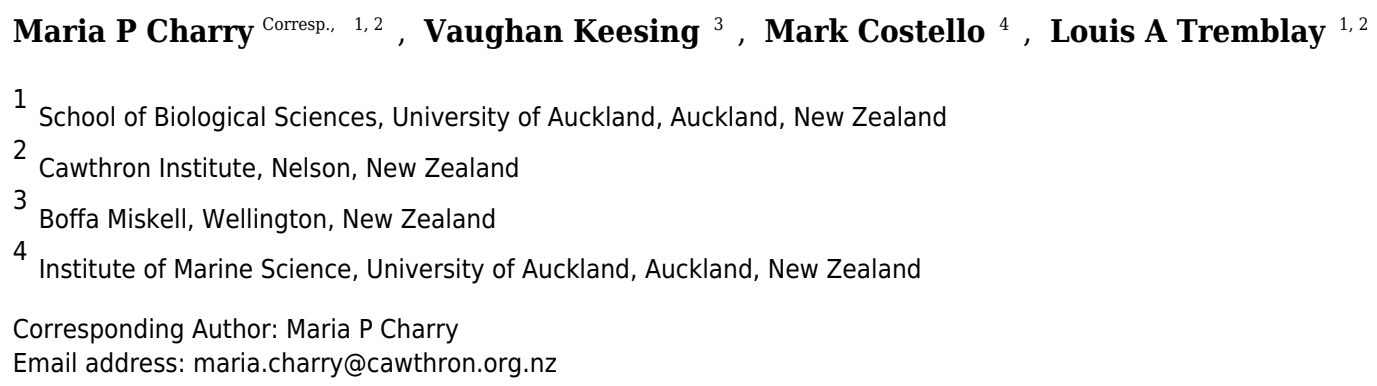

Urban estuarine sediments are sinks to a range of contaminants of anthropogenic origin, and a key challenge is to characterize the risk of these compounds to receiving environments. In this study, the toxicity of urban estuarine sediments was tested using acute and chronic bioassays in the benthic harpacticoid Quinquelaophonte sp., and in the planktonic calanoid Gladioferens pectinatus, two New Zealand copepod species. The sediment samples from the estuary tributary sites significantly impacted reproduction in Quinquelaophonte sp. However, results from one of the estuary sites were not significantly different to those from the tributaries sites, suggesting that chemicals other than trace metals, polycyclic aromatic hydrocarbons and ammonia may be the causative stressors. Sediment elutriate samples had significant effects on reproductive endpoints in $G$. pectinatus, and on the induction of DNA damage in cells, as shown by the comet assay. The results indicate that sediment contamination at the Ahuriri Estuary has the potential to impact biological processes of benthic and pelagic organisms. The approach used provides a standardised methodology to assess the toxicity of estuarine sediments. 


\section{Assessment of the ecotoxicity of urban estuarine sediment 2 using benthic and pelagic copepod bioassays}

3

4 Maria P. Charry ${ }^{1,2, *}$, Vaughan Keesing ${ }^{3}$, Mark Costello ${ }^{4}$, Louis A Tremblay ${ }^{1,2}$

$5{ }^{1}$ Cawthron Institute, Private Bag 2, Nelson 7042, New Zealand

$6{ }^{2}$ School of Biological Sciences, University of Auckland, Auckland 1142, New Zealand

$7 \quad{ }^{3}$ Boffa Miskell Ltd, PO Box 13340, Wellington 6142, New Zealand

$8{ }^{4}$ Institute of Marine Science, University of Auckland, Auckland 1142, New Zealand

9

10

11

12

13

14

15

16

*Corresponding Author:

Maria Charry

98 Halifax Street East, Nelson 7010, New Zealand

Email address: maria.charry@cawthron.org.nz 


\section{Abstract}

18 Urban estuarine sediments are sinks to a range of contaminants of anthropogenic origin, and a key

19 challenge is to characterize the risk of these compounds to receiving environments. In this study,

20 the toxicity of urban estuarine sediments was tested using acute and chronic bioassays in the

21 benthic harpacticoid Quinquelaophonte sp., and in the planktonic calanoid Gladioferens

22 pectinatus, two New Zealand copepod species. The sediment samples from the estuary tributary

23 sites significantly impacted reproduction in Quinquelaophonte sp. However, results from one of

24 the estuary sites were not significantly different to those from the tributaries sites, suggesting that

25 chemicals other than trace metals, polycyclic aromatic hydrocarbons and ammonia may be the

26 causative stressors. Sediment elutriate samples had significant effects on reproductive endpoints

27 in G. pectinatus, and on the induction of DNA damage in cells, as shown by the comet assay. The

28 results indicate that sediment contamination at the Ahuriri Estuary has the potential to impact

29 biological processes of benthic and pelagic organisms. The approach used provides a standardised methodology to assess the toxicity of estuarine sediments. 


\section{Introduction}

Population growth in coastal areas has resulted in the degradation of estuarine habitats and loss of biodiversity (Lotze et al. 2006; Micheli et al. 2013) . Over $40 \%$ of the worldwide population lives within $100 \mathrm{~km}$ of the coast, and in New Zealand, 75\% of human settlements are within $10 \mathrm{~km}$ of the coast (Sale et al. 2014; Statistics New Zealand 2006). The growing demand for resources and services has increased the pressure for agricultural and industrial activities, and urban development (Neumann et al. 2015; van Vliet et al. 2015). Estuaries have become highly vulnerable to this pressure, due to the continuous input of municipal, agricultural and industrial runoff, storm water discharges and accidental wastewater overflows (de los Ríos et al. 2016; Risch et al. 2018; Rodrigues et al. 2017; Willis et al. 2017). These stressors, added to the increase in sedimentation have made estuaries a sink for pollutants with affinity for small particles (Reichelt-Brushett et al. 2017; Swales et al. 2012; Vermeiren et al. 2016).

The potential risk of traditional pollutants and emerging contaminants has become a concern for environmental regulators across New Zealand. The Ahuriri Estuary is recognized as a significant conservation area under the Regional Coastal Environmental Plan for Hawke's Bay (HBRC 2014), and is surrounded by 175 hectares of wetlands of ecological importance. The Purimu Stream and the County Drain were created as buffering zones to reduce stormwater pollution at the Ahuriri Estuary. Smith (2014) reported the presence of contaminants above threshold limits in the Ahuriri Estuary. Recent studies using in vitro and zebrafish (Danio rerio) embryo tests showed that sediment extracts had genotoxicity, teratogenicity and acute toxicity (Boehler et al. 2017; Heinrich et al. 2017)

Studies on chemical extracts can identify chemicals and provide insights into the mechanisms of toxicity but their ability to predict bioavailability or impact on whole organisms is limited (Burton 
1991; Gyuricza et al. 2010). Whole sediment assessments applying in vivo and in vitro approaches can complement extract studies by providing information closer to real field situations. The test organisms are exposed to complex chemical mixtures that can lead to synergistic, additive, or antagonistic toxicities. This is important as not considering toxicity of mixtures can result in under or over-estimation of the environmental risk (Crain et al. 2008; Deruytter et al. 2017; Hasenbein et al. 2015; Przeslawski et al. 2015).

Other endpoints can be measured to further characterise the mechanisms of toxicity like oxidative DNA damage that can lead to genotoxicity (Esperanza et al. 2015; Frenzilli et al. 2009; Pellegri et al. 2014). This can be measured by the comet assay, a single cell electrophoresis technique in which the DNA supercouil is relaxed and exposed electrophoresis, allowing DNA with single and double breaks to migrate towards a charged anode. The amount of DNA visible in the comet tail under fluorescence microscopy provides an estimate of the extent of damage in a cell (Azqueta \& Collins 2013). DNA damage has been reported to affect enzyme functioning and impair the immune system and metabolism of invertebrates, resulting in growth, development, and fitness alterations (Bajpayee et al. 2017; Buschini et al. 2003). Genetic alterations can also lead to mutations and cell proliferations (Mussali-Galante et al. 2014; Simonyan et al. 2016), and inherited teratogenic defects, leading to decreased fitness in populations (Bachère et al. 2017; De Flora et al. 1991; Osman 2014).

The aim of this study was to characterise the toxicity of urban sediment using benthic and pelagic copepod species. The approach combined chemical analysis, bioassays on sediment samples and their elutriates, and the comet assay to estimate genotoxicity potential.

\section{Materials and Methods}


79

80

81

82

83

84

85

86

87

88

89

90

91

92

93

94

95

96

97

Sampling sites and sediment preparation

The Ahuriri Estuary is located north of the City of Napier (population 60,000), on New Zealand's North Island (39 $\left.30^{\prime} \mathrm{S}, 176^{\circ} 52^{\prime} \mathrm{E}\right)$ as described previously (Heinrich et al. 2017). Four sites were selected: two were located 50m upstream from the Estuary at the Old Tutaekuri Riverbed, and at the Humber Street that is exposed to the Tyne Street stormwater drain network. The other two samples were collected downstream from the tributaries sites, at the Ahuriri Estuary (Fig 1). The Waitangi estuary was used as the reference site control (based on previous chemical analysis results), and samples were collected from the mouth of the Ngaruroro river. All samples were collected in August and September 2017, and stored at $4^{\circ} \mathrm{C}$ for two days prior to use Two replicates of sediment cores were collected for each site by scraping the top $0-5 \mathrm{~cm}$ surface sediment. Sample replicates from each site were pooled, and split into subsamples for metal and organic analyses and bioassays. The $\mathrm{pH}$, salinity and Redox of the samples were measured using a multiparameter probe (Hach HQD meter field No.58258.00).

\section{Test species}

Quinquelaophonte sp (M.P Charry et al. 2018, unpublished data) is a benthic harpacticoid copepod, native to New Zealand coastal zones. Its geographic range expands from silty sediments in the Houhora Harbour (North Island), to silty muddy sediments in Portobello Bay in the Otago Harbour (South Island). Gladioferens pectinatus (Bayly 1963) is a pelagic species of calanoid copepod commonly found in New Zealand, Australia and Tasmania (McKinnon \& Arnott 1985). G. pectinatus is highly tolerant to salinity fluctuations, allowing it to distribute from freshwater lakes, estuaries and coastal areas, to open waters (Bayly 1965; Hall \& Burns 2002). Both species were collected, isolated and grown in monocultures in an artificial salt water reticulation system, 
101 with controlled temperature $\left(20^{\circ} \mathrm{C}\right)$, salinity (30ppt), light:dark photoperiod (12hr:12hr), light

102 intensity $(10-15 \mu \mathrm{mol})$ and dissolved oxygen $\left(>7 \mathrm{mg} \cdot \mathrm{L}^{-1}\right)$, following the culturing methods

103 described in Stringer et al. (2012), Chandler and Green (1996) and ISO (2015). Dietary

104 requirements were modified for Gladioferens pectinatus, following Payne \& Rippingale (2000)

105 study. Cultures of Quinquelaophonte sp and G. pectinatus were fed twice per week with a mixed

106 algae diet of $2 \times 10^{6}$ and $5 \times 10^{5}$ cells $\cdot \mathrm{mL}^{-1}$ of Isochrysis galbana, Chaetoceros muelleri and

107 Dunaliella tertiolecta respectively. The three species of microalgae were grown in F2 media at

108 Cawthron Institute.

109 Sediment toxicity test

110 Whole sediment bioassays were conducted following methods described by Chandler et al. (1996),

111 with a modification for Quinquelaophonte sp (Stringer et al. 2014). The assay was conducted over

11214 days on a semi-static system, with a $14 / 10$ light/dark photoperiod, temperature $20 \pm 2{ }^{\circ} \mathrm{C}$, water

113 salinity of $30 \mathrm{ppt} \pm 1, \mathrm{pH} 8 \pm 0.2$ and $\mathrm{DO}>7 \mathrm{mg} \cdot \mathrm{L}^{-1}$. For each treatment there were four replicates.

114 Three replicates were used for biological analysis, and one replicate for physicochemical analyses.

115 Test chambers consisted of $50 \mathrm{~mL}$ borosilicate Erlenmeyers, with 1 diameter apertures in the neck

116 of the flask, covered with a $55 \mu 1$ nylon mesh. These openings allowed for continuous water

117 circulation. Each flask contained 10 grams of sediment, 15 adult males and 15 non-gravid females,

118 previously isolated via glass pipette. Copepods were fed every third day with $2 \times 10^{6}$ cells $\cdot \mathrm{mL}^{-1}$ of

119 an algae mix of I. galbana, C. muelleri and D. tertiolecta. Water parameters were measured at the

120 beginning and end of tests, and endpoints were survival and potential and realized offspring.

121 Elutriate preparation and toxicity test 
122 The 6 day elutriate bioassays used G. pectinatus neonates $(<12 \mathrm{hr}$ old). Elutriates were prepared

123 following ASTM International (2014) guidelines. Briefly, sediments were refrigerated over $24 \mathrm{hr}$,

124 while wet and dry samples were weighed to determine wet weight/volume. Sediment was mixed

125 with artificial salt water $\left(32 \mathrm{~g}\right.$ of Red Sea ${ }^{\circledR}$ Sea salt per one litre of $0.22 \mu \mathrm{m}$ filtered dionized water,

$126 \mathrm{pH}$ adjusted to $8 \pm 0.2)$ to reach a 1:4 (v/v) sediment: water ratio. Samples were placed in an orbital

127 shaker at $100 \mathrm{rpm}$ for 1 hour, and then centrifuged at $3000 \mathrm{rpm}$ for 10 minutes at $4^{\circ} \mathrm{C}$. When

128 necessary, elutriates were filtered with a $150 \mu \mathrm{m}$ sieve, and $\mathrm{pH}$ was adjusted to $8 \pm 0.2$. All test

129 solutions were prepared in flasks previously acid washed with $10 \%$ nitric acid for $24 \mathrm{hr}$, and 130 thoroughly rinsed with deionised water.

131 The ISO/CD 16778 standard (ISO 2015) was followed to assess chronic effects on copepods

132 survival and larval development. Modifications were employed to the protocol due to the hatching

133 difference between $G$. pectinatus and the standard organism, Acartia tonsa. Gravid females were

134 isolated and monitored every $4 \mathrm{hr}$ to ensure nauplii used were in the first larval stage $(<12 \mathrm{hrs}$ from

135 hatching). Neonates were isolated and exposed to each treatment in triplicates. Copepod chambers

136 were maintained at $20 \pm 2^{\circ} \mathrm{C}$ and under a 14:10 light dark photoperiod. Fresh elutriates were

137 prepared and exchanged in test chambers every third day, and nauplii fed a mixture of algae $\left(5 \times 10^{4}\right.$

138 cells $\cdot \mathrm{mL}^{-1}$ ) on the same day. Water samples were collected at the beginning of the test for chemical

139 analysis. At the end of the test, naupliar development and survival were assessed by calculating

140 larval development ratio (realized copepodite/ number of copepodites + number of nauplii) and

141 mortality.

142

143 Comet assay 
144 Genotoxicity was evaluated in G. pectinatus copepodites stage V. The comet assay was performed

145 following the methods described by Singh et al (1988) with modification for copepod cell

146 extractions (Pavlaki et al. 2016; Tartarotti et al. 2013). Each treatment consisted of two replicates

147 of 120 individuals. The positive control was a 15 min exposure to UV-C radiation (Gong et al.

148 2013; Han et al. 2014; Richa et al. 2015; Tartarotti et al. 2013), and the negative control used

149 filtered artificial salt water. Cell suspensions were prepared by homogenizing copepods in a Potter-

150 Elvehjem glass homogenizer with $800 \mu \mathrm{L}$ phosphate-buffered saline (PBS). Heavy materials from

151 the homogenization were let to precipitate before transferring the cell suspension to $600 \mu \mathrm{L}$ micro

152 tubes. Cells were centrifuged at $1.0 \mathrm{rcf}$ for $8 \mathrm{~min}$, the supernatant was discarded, and the cell pellet

153 was resuspended in $85 \mu \mathrm{L}$ Low Melting Point agarose (LMP) mix (0.65\% LMP in TAE 1X). Cell

154 viability was then evaluated using hematoxylin stain to identify number of living cells. Acceptable

155 samples contained around 30,000 cells $\cdot \mathrm{mL}^{-1} .40 \mu \mathrm{L}$ of cell resuspension was added to the slides

156 previously coated with $1 \%$ normal melting point agarose, and cooled on ice for $10 \mathrm{~min}$. A second

157 layer of $0.65 \%$ LMP was added and left to solidify before placing the slides in a lysis buffer

158 solution overnight $(2.5 \mathrm{M} \mathrm{NaCl}, 100 \mathrm{mM}$ Na2EDTA, $10 \mathrm{mM}$ TrisHCl, $10 \%$ DMSO, $1 \%$ Triton

$159 \mathrm{x} 100, \mathrm{pH} 10)$. Slides were then rinsed with cold deionized water and submerged in an

160 electrophoresis buffer (10M NaOH, 200mM Na2EDTA, $\mathrm{pH}>13)$ for 15 min to allow for DNA

161 unwinding. Electrophoresis followed for $15 \mathrm{~min}$ at V43 and $300 \mathrm{~mA}$ in a horizontal gel

162 electrophoresis tank (Bio-rad Power Pac basic cat. no. 164-5050). Slides were then rinsed 3 times

163 in neutralizing buffer $(0.4 \mathrm{M}$ Tris $\mathrm{HCl})$, followed by dehydration in $100 \%$ ethanol for $20 \mathrm{~min}$ at

$1644^{\circ} \mathrm{C}$. Slides were stained with $50 \mu \mathrm{L}$ SafeRed $(3 \mu \mathrm{L} / 50 \mathrm{~mL}$ TAE $1 \mathrm{X})$, and cell counts were done

165 with a fluorescence microscope with a 200 x magnification lens. Comet Assay VI Image analysis 
166 system, PI, UK (V4.3.2) was used to determine tail DNA\%, tail length and tail moment in treated 167 cells.

168 Chemical analyses

169 Elutriate samples were digested in two percent $\mathrm{HNO}_{3}$ until analysed through Inductively Coupled

170 Plasma Mass Spectrometry (ICP-MS Agilent 7500cx) for metal analysis. Polycyclic aromatic

171 hydrocarbons (PAHs) in elutriate were analysed by liquid extraction followed by GC-MS SIM by

172 a commercial analytical laboratory (Hill Laboratories, Hamilton, NZ). All sediment samples were

173 dried for $24 \mathrm{hr}$ at $35^{\circ} \mathrm{C}$ and sieved ( $<2 \mathrm{~mm}$ fraction). Metal samples were digested in nitric acid 174 and analysed with ICP-MS, following US EPA 200.2 protocol. PAH concentrations were analysed 175 by sonication extraction, SPE clean up and GC-MS SIM analysis (US EPA 8270C). All organic 176 compound results were normalized to $1 \%$ organic carbon to allow for direct comparison with the 177 sediment and water quality guidelines (ANZECC 2000).

178 Statistical analysis

179 Results were normalized to percent of control. Homogeneity of variance was tested using Levene's 180 test $(\mathrm{p}<0.05)$. One-way ANOVA with Dunnet's post hoc test was conducted to identify differences 181 between treatments and controls(ISO 2015; Stringer et al. 2014). Comet assay raw data was log 182 transformed for normality. Data meeting normality assumptions was analysed with one-way 183 ANOVA and Dunnet post hoc test. For data with variance not homogenized after log 184 transformation (Levene's test $\mathrm{p}<0.05$ ), non-parametric Kruskal-Wallis test with a Dunn's multiple 185 comparison test were used (Pellegri et al. 2014). The R software drc, dplyr and car packages were 186 used for the analyses and graphs.

\section{Results}


189

190

191

192

193

194

195

196

197

Only the zinc concentrations of the Old Tutaekuri riverbed and at the Humber Street drain sediment samples were above the ANZECC interim sediment quality guideline (ISQG) low value (Table 1). Acenaphthylene and acenaphthene were the only polycyclic aromatic hydrocarbons above the ANZECC ISQG-low values at the Humber Estuary site (Table S1). Elevated levels of total recoverable phosphorus were found in all samples with a much higher level at the Humber drain site (Table 2). Ammonia levels were within normal limits for all sites (ANZECC 2000; Batley \& Simpson 2009), suggesting no masking influence on the toxicity of the samples.

All bioassays parameters met the acceptability criteria (adult survival $>80 \%, \mathrm{pH} 8 \pm 0.2$, salinity $30 \pm 1$ ppt, $\mathrm{DO} \geq 8$, temperature $20 \pm 2{ }^{\circ} \mathrm{C}$ ) (ISO 14669). There was no difference between the control groups except for potential offspring with the Waitangui Estuary sample in the Quinquelaophonte $s p$ tests $(\mathrm{P}<0.001$; Fig 2$)$. There were significant differences between the Humber Drain, Humber Estuary and Old Tutaekuri riverbed sites and the control groups for the survival and reproduction success endpoints $(\mathrm{P}<0.001$; Fig 2).

\section{Water column toxicity}

Many of the sediment elutriate samples had dissolved trace metals at levels above ANZECC water quality guidelines except for cadmium (Table 3). All sites, including the reference site (Waitangi Estuary), had zinc levels above ANZECC trigger values for a level of protection of 95\%. Copper level at the Waitangi site was also above the ANZECC water quality guideline.

The tests met the ISO 16778 (2016) quality assurance standards. Nauplii survival in samples from all sites was significantly different from the control, especially at the Old Turaekuri Riverbed site and the Humber Estuary (Fig 3A). There were no differences in the larval development between 
210 the control, the Waitangi Estuary site and the Old Turaekuri Estuary elutriates ( $>0.05$; Fig 3B).

211 The Old Tutaekuri Riverbed elutriates was the most toxic to G. pectinatus larval development

$212(\mathrm{P}<0.01$; Fig 3B).

213 Comet assay

214 The comet assay was not done on the Waitangi Estuary as it was not sampled at the same time as

215 the other sites. Test acceptability was based on the statistically significant difference between a

216 negative and a positive control $(\mathrm{P}<0.001)$. A significant difference was identified between the

217 DNA damage from the negative and the positive controls (Dunn's, $\mathrm{p}<0.05$ ) on the three parameters

218 measured (tail moment, intensity and length). There were no differences in tail moment and tail

219 intensity between the negative control and the estuary sites. The Old Tutaekuri Riverbed samples

220 induced DNA damage as indicated by the tail moment and tail intensity (DNA\%) (Fig 4). There

221 was no significant DNA damage in samples from Humber Drain based on tail intensity endpoint,

222 however results from tail moment suggest a marginal significance $(p=0.06)$.

\section{Discussion}

224 Between 79 and $87 \%$ of runoff loads have been attributed to urban runoff (residential galvanized

225 roofs and urban roads), with $86 \%$ of the load containing zinc, especially after wet events (Davis \&

226 Birch 2010; Li et al. 2015). Metal concentrations observed in this study were comparable to earlier

227 reports at the Ahuriri Estuary (Smith 2014), and studies in urbanized New Zealand cities (Charters

228 et al. 2016; Mills 2016) and overseas (Ács et al. 2016). The results of metals in the systems studied

229 suggest that stormwater runoff is a major source of metals in the estuary, specially at the Old

230 Tutaekury Riverbed, and Humber Drain samples.

231 The high mortality and low reproduction of Quinquelaophonte sp in the Humber Estuary sample

232 could not be fully explained by the individual metal or PAH content (except for acenaphthylene 
233 and acenaphthene which were above the ISQG-low values). This suggests the presence of multiple

234 stressors affecting the toxicity in copepods. In this study, the Humber Estuary site had the highest

235 sum of low molecular weight PAHs (Table S1). Recent studies have shown that copepods can

236 significantly bioaccumulate PAHs, even when these are below threshold values (Cailleaud et al.

237 2009). However, low weight PAHs can be eliminated more efficiently than high molecular PAHs

238 due to their lower hydrophobicity nature (Almeda et al. 2013). This could have partially

239 contributed to the high mortality of copepods (91\%) exposed to the Humber Estuary sample, and

240 the unsuccess in egg hatching. Our study aligns with those conducted by Boehler et al. (2017) and

241 Heinrich (2017) on extracts from sediment samples collected near the Ahuriri Estuary. They

242 showed multiple toxicity responses including androgenic and glucocorticoid activities in cell lines,

243 and moderate teratogenicity in zebrafish embryos exposed to PAHs and musk extracts mixtures at

244 concentrations as low as $1.6 \mathrm{mg}$ SEQ. $\mathrm{mL}-1$.

245 The total mortality of copepods in the tributary sites can be partially explained by the concentration

246 of zinc. Stringer (2014) calculated a zinc $\mathrm{LC}_{50}$ of $196 \mathrm{mg}$. Kg-1 and a mobility inhibition $\mathrm{EC}_{50}$ of

247137 mg.Kg -1 for Quinquelaophonte sp. The results from the drain and riverbed samples were well

248 above that value (310 and $280 \mathrm{mg}$. Kg-1 respectively), suggesting that zinc had an effect on the

249 mobility and mortality of Quinquelaophonte sp individuals during the 14-day exposure.

250 Physicochemical results showed that the Humber Estuary samples had higher redox potential,

251 which can trigger sulphides and trace metal sulphides oxidation increasing metal bioavailability in

252 pore water (Chapman et al. 1998; Kalnejais et al. 2015; Lu et al. 2016). In addition, the presence

253 of mucilage (predominantly from diatom) was also observed to cover the sediment samples from

254 the Humber Estuary site at the end of the tests. Mucilage has been reported to affect copepod's

255 grazing ability (Malej \& Harris 1993; Pančić \& Kiørboe 2018), and cause teratogenic effects in 
256 the gonadal tissue, affecting reproductive success (Ianora et al. 2011; Wolfram et al. 2014). Further

257 studies are needed to confirm the contribution of these stressors to the toxicity.

258 Bioassays using $G$. pectinatus have been confirmed as good indicators for the toxicity of water

259 dissolved compounds through contact or ingestion. Despite of the reduction of metal

260 concentrations from the tributaries to the estuary sites (zinc and lead dropping by $2.27 \mathrm{X}$ and $2.5 \mathrm{X}$

261 respectively), survival and larval development were significantly affected. The toxicity of the

262 sediment samples to G. pectinatus is unlikely to be solely due to independent metals, as the levels

263 from the estuary sites were similar to those measured in the Waitangi reference and yet, there were

264 differences between the larval development ratio. The presence of other compounds not addressed

265 in this paper (e.i. organochlorine compounds and emerging contaminants) may have further

266 influenced the toxicity in G. pectinatus, as reported in Boehler (2017). This may be due to the

267 higher exposure to pollutants emerging from the Napier city, while the Waitangi estuary is

268 distanced from the urban stormwater and waste water runoff. Extensive literature has reported the

269 effect of additive toxicity of chemicals mixtures in marine invertebrates reproductive success and

270 mortality (Cooper et al. 2009; Hagopian-Schlekat et al. 2001; Picone et al. 2018). However, these

271 effects highly depend on the type of interaction (metal-metal, metal-organic, organic- organic) and

272 on the concentration of each compounds in the mixture, which can either trigger synergistic,

273 antagonistic, or non-interactive toxicities (Gauthier et al. 2014; Nys et al. 2016; Traudt et al. 2017).

274 A recently published framework for ecological risk assessment (Nys et al. 2018) was developed to

275 better characterise the bioavailability of metal mixtures, based on a sensitive species distribution

276 (SSD) model. This approach could be further addressed when assessing community impacts at the

277 Ahuriri estuary. 
279 The comet assay is a well recognised method to measure DNA damage in individual cells, and an 280 accepted tool for environmental monitoring (Colin et al. 2016; de Lapuente et al. 2015; Martins \& 281 Costa 2014). The present study confirms the genotoxicity in the Old Tutaekuri samples, and the 282 potential genotoxicity at the Humber drain, previously characterised with sediment extracts of 283 organic compounds from the Ahuriri estuary (Boehler et al. 2017; Heinrich et al. 2017). The 284 Humber Drain and Old Tutaekuri Riverbed sites had zinc and lead concentrations above guidelines 285 values. Zinc has been reported to induce low levels of DNA damage in zooplankton copepods 286 (Goswami et al. 2014), the marine clam Ruditapes philippinarum, rainbow trout Oncorhynchus mykiss, and grasshopper Chorthippus brunneus (Augustyniak M 2006; Marisa et al. 2016). However, while lead genotoxicity has not been sufficiently studied in copepods, it has been reported to be significant in amphipod haemocytes and spermatozoa at $25 \mu \mathrm{g}$. $\mathrm{L}^{-1}$ (Di Donato et

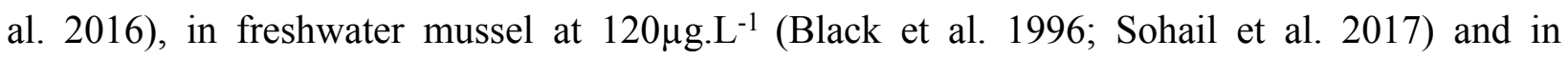
polychaetes at $100 \mu \mathrm{g}$. L-1 after 3 days (Singh et al. 2017).

292

293

In addition, multiple co-genotoxic mechanisms between chemical compounds have been reported on aquatic organisms (Gauthier et al. 2014). These mechanisms include the inhibitory effect of metals on the cytochrome P450, essential for PAHs detoxification; the enhanced production of reactive oxygenated species (ROS) which translates into cellular oxidative stress, and the effects of PAH on membrane integrity, which enhances the permeability to metals. This indicates that mixtures of organic and inorganic chemicals can modulate synergistic, additive or antagonistic toxicities at the cellular and genetic level (Di Poi et al. 2018; Kousar \& Javed 2015; Warne \& Hawker 1995).

The initial protective mechanism of copepods to minimize cellular and DNA damage is to metabolize and eliminate toxicants (Han et al. 2017). However, in the presence of toxicants with 
302 pharmacological modes of action (non-specific disruption or overloading of enzyme activities),

303 the enzymes in charge of metabolising compounds and lipid storage regulators may be inhibited.

304 The presence of compounds with these modes of action were identified at the Humber drain and 305 the Old Tutaekuri riverbed in previous studies at 0.012 and $0.0034 \mathrm{mg}$. Kg-1 respectively (Boehler

306 et al. 2017). Pharmacological effects have been reported in the pelagic copepod Calanus

307 finmarchicus exposed to naphthalene, pyrene, crude oil (Han et al. 2015; Hansen et al. 2008),

308 Acartia tonsa exposed to four synthetic musk substances (Wollenberger et al. 2003), Tigriopus

309 japonicus exposed to polybrominated diphenyl ethers (Han et al. 2015), and Nitocra spinipes

310 exposed to galaxolide (Breitholtz et al. 2003). This may suggest that the chemicals present at the

311 impacted estuary sites may have modes of action affecting the precursor of larval molding and

312 deoxidation (P450 enzymes such as CYP330A1 or CYP305A1) as shown on the bioassays, as

313 opposed to directly fractioning DNA brands (Hansen et al. 2008). Further, DNA repairing

314 mechanisms present in copepods remains to be confirmed.

315 It has been suggested that risk assessment frameworks and decision support systems consider the

316 genotoxicity of chemical mixtures as part of a weight of evidence approach. This has been

317 demonstrated by the method integrating nine lines of evidence in contaminated estuaries in

318 Portugal (Caeiro et al. 2017), the policy frameworks and risk assessment tools at contaminated

319 sites in the Netherlands (Dagnino et al. 2008), and the acceptance of genotoxic tools as one of the

320 standard monitoring strategies within the European Union Water and Marine Strategy Framework

321 Directives (Allan et al. 2006; Martins \& Costa 2015).

\section{Conclusion}

323 The sediment and elutriate samples from the urban Ahuriri Estuary tributaries were genotoxic and

324 impacted reproduction in the two copepod bioassays. The toxicity from the estuaries sites was 
325 lower than that of the tributaries, but genotoxicity and reproduction inhibition were evidenced.

326 This confirms the bioavailability of biologically active chemicals in the sediment samples. The

327 approach using bioassays in pelagic and benthic copepod species was successful to characterise

328 the toxicity of urban sediment. The results provides useful effects-based information to inform

329 environmental managers.

\section{Acknowledgements}

331 The authors would like to thank Anna Madarasz-Smith for the collection of sediment samples and

332 for the access to chemical data; Olivier Champeau for assistance with the comet assay and Steve

333 Web for his help with copepod histology and cells identification.

\section{References}

336

337

338

339

340

341

342

343

344

345

346

347

348

349

350

351

352

353

354

355

356

357

358

359

360

Ács A, Vehovszky Á, Győri J, and Farkas A. 2016. Seasonal and size-related variation of subcellular biomarkers in quagga mussels (Dreissena bugensis) inhabiting sites affected by moderate contamination with complex mixtures of pollutants. Environmental Monitoring and Assessment 188:426. 10.1007/s10661-016-5432-y

Allan IJ, Vrana B, Greenwood R, Mills GA, Roig B, and Gonzalez C. 2006. A "toolbox" for biological and chemical monitoring requirements for the European Union's Water Framework Directive. Talanta 69:302-322. 10.1016/j.talanta.2005.09.043

Almeda R, Wambaugh Z, Wang Z, Hyatt C, Liu Z, and Buskey EJ. 2013. Interactions between Zooplankton and Crude Oil: Toxic Effects and Bioaccumulation of Polycyclic Aromatic Hydrocarbons. PLoS One 8:e67212. 10.1371/journal.pone.0067212

ANZECC. 2000. Australian and New Zealand Guidelines for Fresh and Marine Water Quality. Australian and New Zealand Environmental and Conservation Council, Agriculture and Resource Management Council of Australia and New Zealand, Canberra.

ASTM E. 2014. 1391-03 (2014). Standard Guide for Collection, Storage, Characterization and Manipulation of Sediments for Toxicological Testing for Selection of Samplers used to collect Benthic Invertebrates E1391-03.

Augustyniak M JJ, Przybyłowicz WJ, Mesjasz-Przybyłowicz J, Babczyńska A, Paweł M. 2006. Zinc-induced DNA damage and the distribution of metals in the brain of grasshoppers by the comet assay and micro-PIXE. Comparative Biochemistry and Physiology Part C: Toxicology \& Pharmacology 144:242-251. https://doi.org/10.1016/j.cbpc.2006.09.003

Azqueta A, and Collins AR. 2013. The essential comet assay: a comprehensive guide to measuring DNA damage and repair. Archives of Toxicology Archiv für Toxikologie 87:949-968. http://dx.doi.org/10.1007/s00204-013-1070-0

Bachère $E$, Barranger A, Bruno R, Rouxel J, Menard D, Piquemal D, and Akcha F. 2017. Parental diuronexposure alters offspring transcriptome and fitness in Pacific oyster Crassostrea gigas. 
400

401

402

403

404

405

406

407

408

Ecotoxicology and Environmental Safety 142:51-58.

https://doi.org/10.1016/j.ecoenv.2017.03.030

Bajpayee M, Kumar A, and Dhawan A. 2017. Chapter 1 The Comet Assay: A Versatile Tool for Assessing DNA Damage. The Comet Assay in Toxicology: The Royal Society of Chemistry, 1-64.

Batley GE, and Simpson SL. 2009. Development of guidelines for ammonia in estuarine and marine water systems. Marine Pollution Bulletin 58:1472-1476. https://doi.org/10.1016/j.marpolbul.2009.06.005

Bayly I. 1963. A Revision of the Coastal Water Genus Gladioferens (Copepoda: Calanoida). Marine and Freshwater Research 14:194-217. https://doi.org/10.1071/MF9630194

Bayly I. 1965. Ecological studies on the planktonic Copepoda of the Brisbane River estuary with special reference to Gladioferens pectinatus (Brady)(Calanoida). Marine and Freshwater Research 16:315-350.

Black MC, Ferrell JR, Horning RC, and Martin LK. 1996. DNA strand breakage in freshwater mussels (Anodonta grandis) exposed to lead in the laboratory and field. Environmental Toxicology and Chemistry 15:802-808. 10.1002/etc.5620150528

Boehler S, Strecker R, Heinrich P, Prochazka E, Northcott GL, Ataria JM, Leusch FDL, Braunbeck T, and Tremblay LA. 2017. Assessment of urban stream sediment pollutants entering estuaries using chemical analysis and multiple bioassays to characterise biological activities. Science of the Total Environment 593-594:498-507. https://doi.org/10.1016/j.scitotenv.2017.03.209

Breitholtz M, Wollenberger L, and Dinan L. 2003. Effects of four synthetic musks on the life cycle of the harpacticoid copepod Nitocra spinipes. Aquatic Toxicology 63:103-118. https://doi.org/10.1016/S0166-445X(02)00159-5

Burton GA. 1991. Assessing the toxicity of freshwater sediments. Environmental Toxicology and Chemistry 10:1585-1627.

Buschini A, Carboni P, Martino A, Poli P, and Rossi C. 2003. Effects of temperature on baseline and genotoxicant-induced DNA damage in haemocytes of Dreissena polymorpha. Mutation Research/Genetic Toxicology and Environmental Mutagenesis 537:81-92.

Caeiro S, Vaz-Fernandes P, Martinho AP, Costa PM, Silva MJ, Lavinha J, Matias-Dias C, Machado A, Castanheira I, and Costa MH. 2017. Environmental risk assessment in a contaminated estuary: An integrated weight of evidence approach as a decision support tool. Ocean \& Coastal Management 143:51-62. https://doi.org/10.1016/j.ocecoaman.2016.09.026

Cailleaud K, Budzinski H, Le Menach K, Souissi S, and Forget-Leray J. 2009. Uptake and elimination of hydrophobic organic contaminants in estuarine copepods: an experimental study. Environmental Toxicology and Chemistry 28:239-246. http://dx.doi.org/10.1897/07-664.1

Chandler GT, and Green AS. 1996. A 14 day harpacticoid copepod reproductive bioassay for laboratory and field contaminated muddy sediments. Boca Raton, FL.: CRC Press.

Chapman PM, Wang F, Janssen C, Persoone G, and Allen HE. 1998. Ecotoxicology of metals in aquatic sediments: binding and release, bioavailability, risk assessment, and remediation. Canadian Journal of Fisheries and Aquatic Sciences 55:2221-2243.

Charters FJ, Cochrane TA, and O'Sullivan AD. 2016. Untreated runoff quality from roof and road surfaces in a low intensity rainfall climate. Science of the Total Environment 550:265-272. https://doi.org/10.1016/j.scitotenv.2016.01.093

Colin N, Porte C, Fernandes D, Barata C, Padrós F, Carrassón M, Monroy M, Cano-Rocabayera O, de Sostoa A, Piña B, and Maceda-Veiga A. 2016. Ecological relevance of biomarkers in monitoring studies of macro-invertebrates and fish in Mediterranean rivers. Science of the Total Environment 540:307-323. https://doi.org/10.1016/j.scitotenv.2015.06.099

Cooper NL, Bidwell JR, and Kumar A. 2009. Toxicity of copper, lead, and zinc mixtures to Ceriodaphnia dubia and Daphnia carinata. Ecotoxicology and Environmental Safety 72:1523-1528. 
409

410

411

412

413

414

415

416

417

418

419

420

421

422

423

424

425

426

427

428

429

430

431

432

433

434

435

436

437

438

439

440

441

442

443

444

445

446

447

448

449

450

451

452

453

454

Crain CM, Kroeker K, and Halpern BS. 2008. Interactive and cumulative effects of multiple human stressors in marine systems. Ecology Letters 11:1304-1315.

Dagnino A, Sforzini S, Dondero F, Fenoglio S, Bona E, Jensen J, and Viarengo A. 2008. A weight-of-evidence approach for the integration of environmental "triad" data to assess ecological risk and biological vulnerability. Integrated Environmental Assessment and Management 4:314-326.

Davis B, and Birch G. 2010. Comparison of heavy metal loads in stormwater runoff from major and minor urban roads using pollutant yield rating curves. Environmental Pollution 158:2541-2545. https://doi.org/10.1016/j.envpol.2010.05.021

De Flora S, Bagnasco M, and Zanacchi P. 1991. Genotoxic, carcinogenic, and teratogenic hazards in the marine environment, with special reference to the Mediterranean Sea. Mutation Research/Reviews in Genetic Toxicology 258:285-320.

de Lapuente J, Lourenço J, Mendo SA, Borràs M, Martins MG, Costa PM, and Pacheco M. 2015. The Comet Assay and its applications in the field of ecotoxicology: a mature tool that continues to expand its perspectives. Frontiers in genetics 6:180.

de los Ríos A, Pérez L, Echavarri-Erasun B, Serrano T, Barbero MC, Ortiz-Zarragoitia M, Orbea A, Juanes $J A$, and Cajaraville MP. 2016. Measuring biological responses at different levels of organisation to assess the effects of diffuse contamination derived from harbour and industrial activities in estuarine areas. Marine Pollution Bulletin 103:301-312.

https://doi.org/10.1016/j.marpolbul.2015.11.056

Deruytter D, Baert JM, Nevejan N, Schamphelaere KACD, and Janssen CR. 2017. Mixture toxicity in the marine environment: Model development and evidence for synergism at environmental concentrations. Environmental Toxicology and Chemistry 36:3471-3479. doi:10.1002/etc.3913

Di Donato G, De Matthaeis E, Ronci L, and Setini A. 2016. Genotoxicity biomarkers in the amphipod Gammarus elvirae exposed in vivo to mercury and lead, and basal levels of DNA damage in two cell types. Chemistry and Ecology 32:843-857. 10.1080/02757540.2016.1201078

Di Poi C, Costil K, Bouchart V, and Halm-Lemeille M-P. 2018. Toxicity assessment of five emerging pollutants, alone and in binary or ternary mixtures, towards three aquatic organisms. Environmental Science and Pollution Research 25:6122-6134. 10.1007/s11356-017-9306-9

Esperanza M, Cid Á, Herrero C, and Rioboo C. 2015. Acute effects of a prooxidant herbicide on the microalga Chlamydomonas reinhardtii: Screening cytotoxicity and genotoxicity endpoints. Aquatic toxicology (Amsterdam, Netherlands) 165:210-221. http://dx.doi.org/10.1016/j.aquatox.2015.06.004

Frenzilli G, Nigro M, and Lyons B. 2009. The Comet assay for the evaluation of genotoxic impact in aquatic environments. Mutation Research/Reviews in Mutation Research 681:80-92.

Gauthier PT, Norwood WP, Prepas EE, and Pyle GG. 2014. Metal-PAH mixtures in the aquatic environment: A review of co-toxic mechanisms leading to more-than-additive outcomes. Aquatic Toxicology 154:253-269. https://doi.org/10.1016/j.aquatox.2014.05.026

Gong C, Wang A, Chen H, Jiang W, Tan L, and Hu Z. 2013. Effects of UV-C radiation on the survival of copepods and oocysts: implications for drinking water processing facilities. Hydrobiologia 714:111. http://dx.doi.org/10.1007/s10750-013-1495-8

Goswami P, Thirunavukkarasu S, Godhantaraman N, and Munuswamy N. 2014. Monitoring of genotoxicity in marine zooplankton induced by toxic metals in Ennore estuary, Southeast coast of India. Marine Pollution Bulletin 88:70-80. http://dx.doi.org/10.1016/j.marpolbul.2014.09.025

Gyuricza V, Fodor F, and Szigeti Z. 2010. Phytotoxic effects of heavy metal contaminated soil reveal limitations of extract-based ecotoxicological tests. Water, Air, \& Soil Pollution 210:113-122. 
455

456

457

458

459

460

461

462

463

464

465

466

467

468

469

470

471

472

473

474

475

476

477

478

479

480

481

482

483

484

485

486

487

488

489

490

491

492

493

494

495

496

497

498

499

500

Hagopian-Schlekat T, Chandler G, and Shaw TJ. 2001. Acute toxicity of five sediment-associated metals, individually and in a mixture, to the estuarine meiobenthic harpacticoid copepod Amphiascus tenuiremis. Marine Environmental Research 51:247-264.

Hall CJ, and Burns CW. 2002. Environmental gradients and zooplankton distribution in a shallow, tidal lake. Archiv für Hydrobiologie-Hauptbände:485-497.

Han J, Won E-J, Kang H-M, Lee M-C, Jeong C-B, Kim H-S, Hwang D-S, and Lee J-S. 2017. Marine copepod cytochrome $\mathrm{P} 450$ genes and their applications for molecular ecotoxicological studies in response to oil pollution. Marine Pollution Bulletin 124:953-961.

https://doi.org/10.1016/j.marpolbul.2016.09.048

Han J, Won E-J, Lee B-Y, Hwang U-K, Kim I-C, Yim JH, Leung KMY, Lee YS, and Lee J-S. 2014. Gamma rays induce DNA damage and oxidative stress associated with impaired growth and reproduction in the copepod Tigriopus japonicus. Aquatic Toxicology 152:264-272.

Han J, Won E-J, Lee M-C, Seo JS, Lee S-J, and Lee J-S. 2015. Developmental retardation, reduced fecundity, and modulated expression of the defensome in the intertidal copepod Tigriopus japonicus exposed to BDE-47 and PFOS. Aquatic Toxicology 165:136-143.

https://doi.org/10.1016/j.aquatox.2015.05.022

Hansen BH, Altin D, Hessen KM, Dahl U, Breitholtz M, Nordtug T, and Olsen AJ. 2008. Expression of ecdysteroids and cytochrome P450 enzymes during lipid turnover and reproduction in Calanus finmarchicus (Crustacea: Copepoda). General and Comparative Endocrinology 158:115-121. https://doi.org/10.1016/j.ygcen.2008.05.013

Hasenbein S, Lawler SP, Geist J, and Connon RE. 2015. The use of growth and behavioral endpoints to assess the effects of pesticide mixtures upon aquatic organisms. Ecotoxicology 24:746-759. 10.1007/s10646-015-1420-1

HBRC. 2014. Hawke's Bay Regional Coastal Environment Plan Operative Hawkes Bay Regional Council, New Zealand. p 240.

Heinrich P, Petschick LL, Northcott GL, Tremblay LA, Ataria JM, and Braunbeck T. 2017. Assessment of cytotoxicity, genotoxicity and 7-ethoxyresorufin-O-deethylase (EROD) induction in sediment extracts from New Zealand urban estuaries. Ecotoxicology 26:211-226. 10.1007/s10646-016$1756-1$

Ianora A, Romano G, Carotenuto Y, Esposito F, Roncalli V, Buttino I, and Miralto A. 2011. Impact of the diatom oxylipin 15S-HEPE on the reproductive success of the copepod Temora stylifera. Hydrobiologia 666:265-275. http://dx.doi.org/10.1007/s10750-010-0420-7

ISO. 2015. International Organization for Standardization. Water Quality-Calanoid Copepod Development Test with Acartia tonsa. ISO/FDIS 16778. Calanoid Copepod Early-life Stage Test with Acartia tonsa. ISO, Geneva.

Kalnejais LH, Martin WR, and Bothner MH. 2015. Porewater dynamics of silver, lead and copper in coastal sediments and implications for benthic metal fluxes. Science of the Total Environment 517:178-194. https://doi.org/10.1016/j.scitotenv.2015.02.011

Kousar S, and Javed M. 2015. Diagnosis of metals induced DNA damage in fish using comet assay. Pakistan Veterinary Journal 35:168-172.

Li D, Wan J, Ma Y, Wang Y, Huang M, and Chen Y. 2015. Stormwater Runoff Pollutant Loading Distributions and Their Correlation with Rainfall and Catchment Characteristics in a Rapidly Industrialized City. PLoS One 10:e0118776. 10.1371/journal.pone.0118776

Lotze HK, Lenihan HS, Bourque BJ, Bradbury RH, Cooke RG, Kay MC, Kidwell SM, Kirby MX, Peterson CH, and Jackson JBC. 2006. Depletion, Degradation, and Recovery Potential of Estuaries and Coastal Seas. Science 312:1806-1809. 10.1126/science.1128035 
501

502

503

504

505

506

507

508

509

510

511

512

513

514

515

516

517

518

519

520

521

522

523

524

525

526

527

528

529

530

531

532

533

534

535

536

537

538

539

540

541

542

543

544

545

546

547

548

Lu J, Yuan F, Zhang F, and Zhao Q. 2016. The study on heavy metal distribution in the sediment of middle tidal flat in Yangtze Estuary, China. Environmental Earth Sciences 75:1-12.

http://dx.doi.org/10.1007/s12665-016-5356-4

Malej A, and Harris RP. 1993. Inhibition of copepod grazing by diatom exudates: a factor in the development of mucus aggregates? Marine Ecology Progress Series:33-42.

Marisa I, Matozzo V, Munari M, Binelli A, Parolini M, Martucci A, Franceschinis E, Brianese N, and Marin MG. 2016. In vivo exposure of the marine clam Ruditapes philippinarum to zinc oxide nanoparticles: responses in gills, digestive gland and haemolymph. Environmental Science and Pollution Research International 23:15275-15293. http://dx.doi.org/10.1007/s11356-016-6690-5

Martins M, and Costa PM. 2014. The comet assay in environmental risk assessment of marine pollutants: applications, assets and handicaps of surveying genotoxicity in non-model organisms. Mutagenesis 30:89-106.

Martins M, and Costa PM. 2015. The comet assay in Environmental Risk Assessment of marine pollutants: applications, assets and handicaps of surveying genotoxicity in non-model organisms. Mutagenesis 30:89-106. 10.1093/mutage/geu037

McKinnon A, and Arnott G. 1985. The developmental stages of Gladioferens pectinatus (Brady, 1899)(Copepoda: Calanoida). New Zealand Journal of Marine and Freshwater Research 19:2142.

Micheli F, Halpern BS, Walbridge S, Ciriaco S, Ferretti F, Fraschetti S, Lewison R, Nykjaer L, and Rosenberg AA. 2013. Cumulative Human Impacts on Mediterranean and Black Sea Marine Ecosystems: Assessing Current Pressures and Opportunities. PLoS One 8:e79889. 10.1371/journal.pone.0079889

Mills GN. 2016. Auckland marine sediment contaminant monitoring: Drury Creek, June 2015. Prepared by Diffuse Sources Ltd for Auckland Council. Auckland Council technical report, TR2016/024.

Mussali-Galante P, Tovar-Sánchez E, Valverde M, and Rojas E. 2014. Genetic Structure and Diversity of Animal Populations Exposed to Metal Pollution. In: Whitacre DM, ed. Reviews of Environmental Contamination and Toxicology, Volume 227. Cham: Springer International Publishing, 79-106.

Neumann B, Vafeidis AT, Zimmermann J, and Nicholls RJ. 2015. Future Coastal Population Growth and Exposure to Sea-Level Rise and Coastal Flooding - A Global Assessment. PLoS One 10:e0118571. 10.1371/journal.pone.0118571

Nys C, Janssen CR, Blust R, Smolders E, and De Schamphelaere KA. 2016. Reproductive toxicity of binary and ternary mixture combinations of nickel, zinc, and lead to Ceriodaphnia dubia is best predicted with the independent action model. Environmental Toxicology and Chemistry 35:1796-1805.

Nys C, Van Regenmortel T, Janssen CR, Oorts K, Smolders E, and De Schamphelaere KA. 2018. A framework for ecological risk assessment of metal mixtures in aquatic systems. Environmental Toxicology and Chemistry 37:623-642.

Osman AGM. 2014. Genotoxicity Tests and Their Contributions in Aquatic Environmental Research. Journal of Environmental Protection Vol.05No.14:9. 10.4236/jep.2014.514132

Pančić M, and Kiørboe T. 2018. Phytoplankton defence mechanisms: traits and trade-offs. Biological Reviews 93:1269-1303. http://dx.doi.org/10.1111/brv.12395

Pavlaki MD, Araújo MJ, Cardoso DN, Silva ARR, Cruz A, Mendo S, Soares AM, Calado R, and Loureiro S. 2016. Ecotoxicity and genotoxicity of cadmium in different marine trophic levels. Environmental Pollution 215:203-212.

Payne M, and Rippingale R. 2000. Evaluation of diets for culture of the calanoid copepod Gladioferens imparipes. Aquaculture 187:85-96.

Pellegri V, Gorbi G, and Buschini A. 2014. Comet assay on Daphnia magna in eco-genotoxicity testing. Aquatic Toxicology 155:261-268. 
549

550

551

552

553

554

555

556

557

558

559

560

561

562

563

564

565

566

567

568

569

570

571

572

573

574

575

576

577

578

579

580

581

582

583

584

585

586

587

588

589

590

591

592

593

594

595

Picone M, Bergamin M, Delaney E, Ghirardini AV, and Kusk KO. 2018. Testing lagoonal sediments with early life stages of the copepod Acartia tonsa (Dana): An approach to assess sediment toxicity in the Venice Lagoon. Ecotoxicology and Environmental Safety 147:217-227.

Przeslawski R, Byrne M, and Mellin C. 2015. A review and meta-analysis of the effects of multiple abiotic stressors on marine embryos and larvae. Global Change Biology 21:2122-2140. doi:10.1111/gcb.12833

Reichelt-Brushett A, Clark M, and Birch G. 2017. Physical and Chemical Factors to Consider when Studying Historical Contamination and Pollution in Estuaries. In: Weckström K, Saunders KM, Gell PA, and Skilbeck CG, eds. Applications of Paleoenvironmental Techniques in Estuarine Studies. Dordrecht: Springer Netherlands, 239-276.

Richa, Sinha RP, and Häder D-P. 2015. Physiological Aspects of UV-Excitation of DNA. In: Barbatti M, Borin AC, and Ullrich S, eds. Photoinduced Phenomena in Nucleic Acids II: DNA Fragments and Phenomenological Aspects. Cham: Springer International Publishing, 203-248.

Risch E, Gasperi J, Gromaire M-C, Chebbo G, Azimi S, Rocher V, Roux P, Rosenbaum RK, and Sinfort C. 2018. Impacts from urban water systems on receiving waters - How to account for severe wetweather events in LCA? Water Research 128:412-423.

https://doi.org/10.1016/j.watres.2017.10.039

Rodrigues SK, Abessa DMS, Rodrigues APdC, Soares-Gomes A, Freitas CB, Santelli RE, Freire AS, and Machado W. 2017. Sediment quality in a metal-contaminated tropical bay assessed with a multiple lines of evidence approach. Environmental Pollution 228:265-276. https://doi.org/10.1016/j.envpol.2017.05.045

Sale PF, Agardy T, Ainsworth CH, Feist BE, Bell JD, Christie P, Hoegh-Guldberg O, Mumby PJ, Feary DA, Saunders MI, Daw TM, Foale SJ, Levin PS, Lindeman KC, Lorenzen K, Pomeroy RS, Allison EH, Bradbury RH, Corrin J, Edwards AJ, Obura DO, Sadovy de Mitcheson YJ, Samoilys MA, and Sheppard CRC. 2014. Transforming management of tropical coastal seas to cope with challenges of the 21st century. Marine Pollution Bulletin 85:8-23. https://doi.org/10.1016/j.marpolbul.2014.06.005

Simonyan A, Gabrielyan B, Minasyan S, Hovhannisyan G, and Aroutiounian R. 2016. Genotoxicity of Water Contaminants from the Basin of Lake Sevan, Armenia Evaluated by the Comet Assay in Gibel Carp (Carassius auratus gibelio) and Tradescantia Bioassays. Bulletin of Environmental Contamination and Toxicology 96:309-313. 10.1007/s00128-015-1720-4

Singh N, Bhagat J, and Ingole BS. 2017. Genotoxicity of two heavy metal compounds: lead nitrate and cobalt chloride in Polychaete Perinereis cultrifera. Environmental Monitoring and Assessment 189:308.

Singh NP, McCoy MT, Tice RR, and Schneider EL. 1988. A simple technique for quantitation of low levels of DNA damage in individual cells. Experimental Cell Research 175:184-191. http://dx.doi.org/10.1016/0014-4827(88)90265-0

Smith S. 2014. Monitoring of benthic effects of stormwater discharges at sites in the Ahuriri Estuary, Napier: 2014 survey. Report prepared for Hawke's Bay Regional Council and Napier City Council Napier, Triplefin Environmental Consulting

Sohail M, Khan M, Qureshi N, and Chaudhry A. 2017. Monitoring DNA Damage in Gills of Freshwater Mussels (Anodonta anatina) Exposed to Heavy Metals.

Statistics New Zealand. 2006. Are New Zealanders living closer to the coast? Available at http://www.stats.govt.nz/browse_for_stats/population/Migration/internal-migration/are-nzsliving-closer-to-coast.aspx (accessed 30 January 2018).

Stringer TJ, Glover CN, Keesing V, Northcott GL, Gaw S, and Tremblay LA. 2014. Development of acute and chronic sediment bioassays with the harpacticoid copepod Quinquelaophonte sp. 
596

597

598

599

600

601

602

603

604

605

606

607

608

609

610

611

612

613

614

615

616

617

618

619

620

621

622

623

624

625

626

627

628

629

Ecotoxicology and Environmental Safety 99:82-91.

http://dx.doi.org/10.1016/j.ecoenv.2013.10.002

Stringer TJ, Glover CN, Keesing V, Northcott GL, and Tremblay LA. 2012. Development of a harpacticoid copepod bioassay: Selection of species and relative sensitivity to zinc, atrazine and phenanthrene. Ecotoxicology and Environmental Safety 80:363-371. http://dx.doi.org/10.1016/j.ecoenv.2012.04.008

Swales A, Gibbs M, Hewitt J, Hailes S, Griffiths R, Olsen G, Ovenden R, and Wadhwa S. 2012. Sediment sources and accumulation rates in the Bay of Islands and implications for macro-benthic fauna, mangrove and saltmarsh habitats. Prepared by NIWA for Northland Regional Council.

Tartarotti B, Saul N, Chakrabarti S, Trattner F, Steinberg CE, and Sommaruga R. 2013. UV-induced DNA damage in Cyclops abyssorum tatricus populations from clear and turbid alpine lakes. Journal of Plankton Research 36:557-566.

Traudt EM, Ranville JF, and Meyer JS. 2017. Acute Toxicity of Ternary Cd-Cu-Ni and Cd-Ni-Zn Mixtures to Daphnia magna: Dominant Metal Pairs Change along a Concentration Gradient. Environmental Science \& Technology 51:4471-4481. 10.1021/acs.est.6b06169

van Vliet J, de Groot HLF, Rietveld P, and Verburg PH. 2015. Manifestations and underlying drivers of agricultural land use change in Europe. Landscape and Urban Planning 133:24-36. https://doi.org/10.1016/j.landurbplan.2014.09.001

Vermeiren P, Muñoz CC, and Ikejima K. 2016. Sources and sinks of plastic debris in estuaries: A conceptual model integrating biological, physical and chemical distribution mechanisms. Marine Pollution Bulletin 113:7-16. https://doi.org/10.1016/j.marpolbul.2016.10.002

Warne MSJ, and Hawker DW. 1995. The Number of Components in a Mixture Determines Whether Synergistic and Antagonistic or Additive Toxicity Predominate: The Funnel Hypothesis. Ecotoxicology and Environmental Safety 31:23-28. https://doi.org/10.1006/eesa.1995.1039

Willis K, Hardesty BD, Kriwoken L, and Wilcox C. 2017. Differentiating littering, urban runoff and marine transport as sources of marine debris in coastal and estuarine environments. Scientific Reports 7:44479.

Wolfram S, Nejstgaard JC, and Pohnert G. 2014. Accumulation of Polyunsaturated Aldehydes in the Gonads of the Copepod Acartia tonsa Revealed by Tailored Fluorescent Probes. PLoS One 9. http://dx.doi.org/10.1371/journal.pone.0112522

Wollenberger L, Breitholtz M, Kusk KO, and Bengtsson B-E. 2003. Inhibition of larval development of the marine copepod Acartia tonsa by four synthetic musk substances. Science of the Total Environment 305:53-64. 
Figure 1

The Ahuriri Estuary and Waitangi Estuary sampling sites.

(A) Old Tutaekuri Estuary site. (B) Old Tutaekuri Riverbed site. (C) Humber Estuary site. (D) Humber Drain site. (E) Waitangi Estuary site. The Old Tutaekuri Riverbed receives most of the inflow from a rural and urban catchment, and the Humber Drain receives stormwater inflow from the Pandora industrial area and residential suburbs.

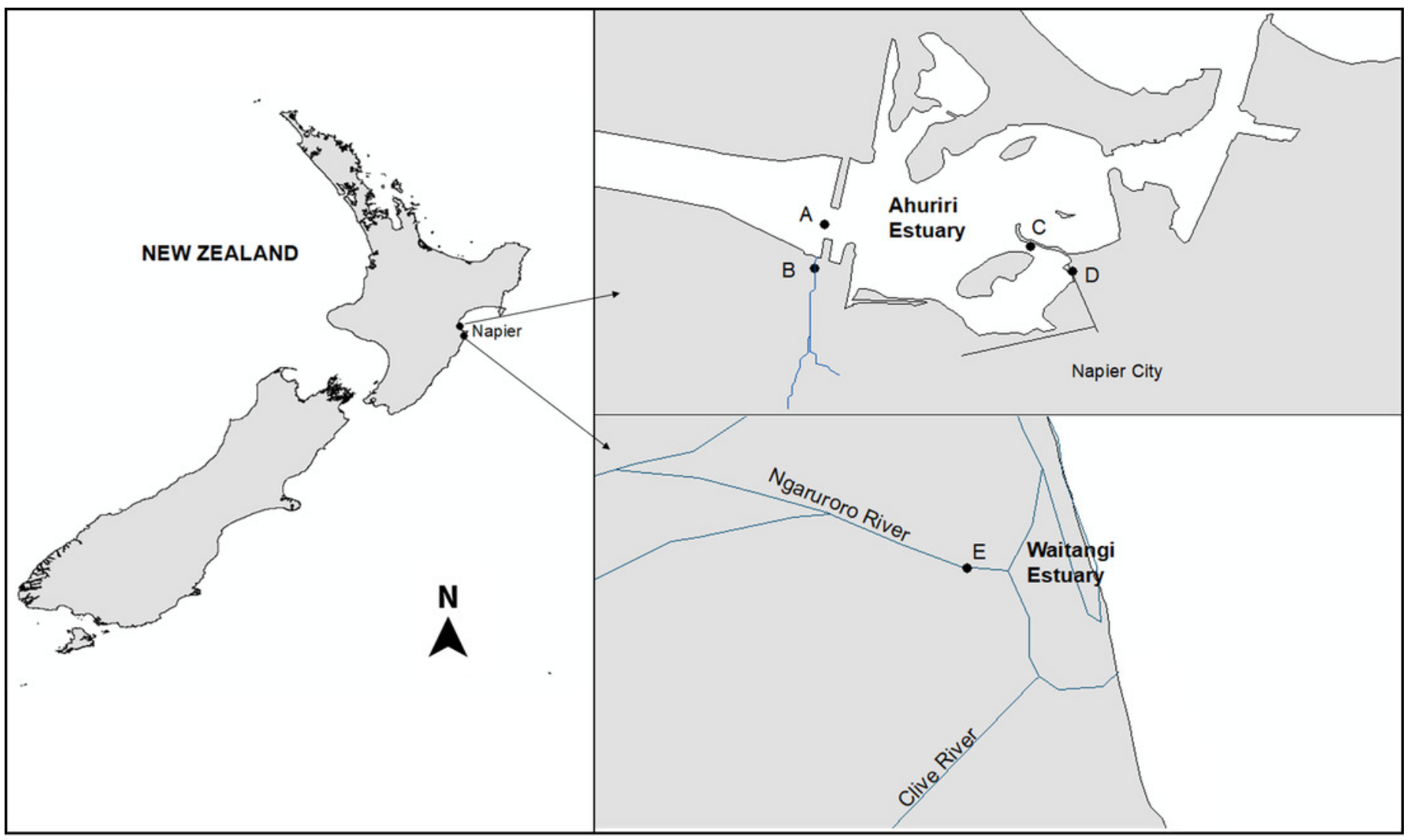




\section{Figure 2}

\section{Results of the 14-day chronic test using the benthic copepod Quinquelaophonte sp exposed to} sediments.

Three endpoints were assessed for the toxicity of sediments from the Ahuriri Estuary and reference site, Waitangi estuary. (A) Survival. (B) Total offspring hatched during the test. (C) Potential offspring (eggs in female pouch). Site codes: Waitangi Estuary (Wa), Old Tutaekuri Estuary (OT Est), Humber Estuary (Hum Est), Old Tutaekuri Riverbed (OT River), Humber Drain (Hum Dr). Diagonal lined bars: control site (Waitangi), white bar: laboratory control sediment, black bars: tested sites. Significance levels: '*' $p<0.05$, ‘**' $p<$ 0.001 Dunnett's multiple comparison against the control.
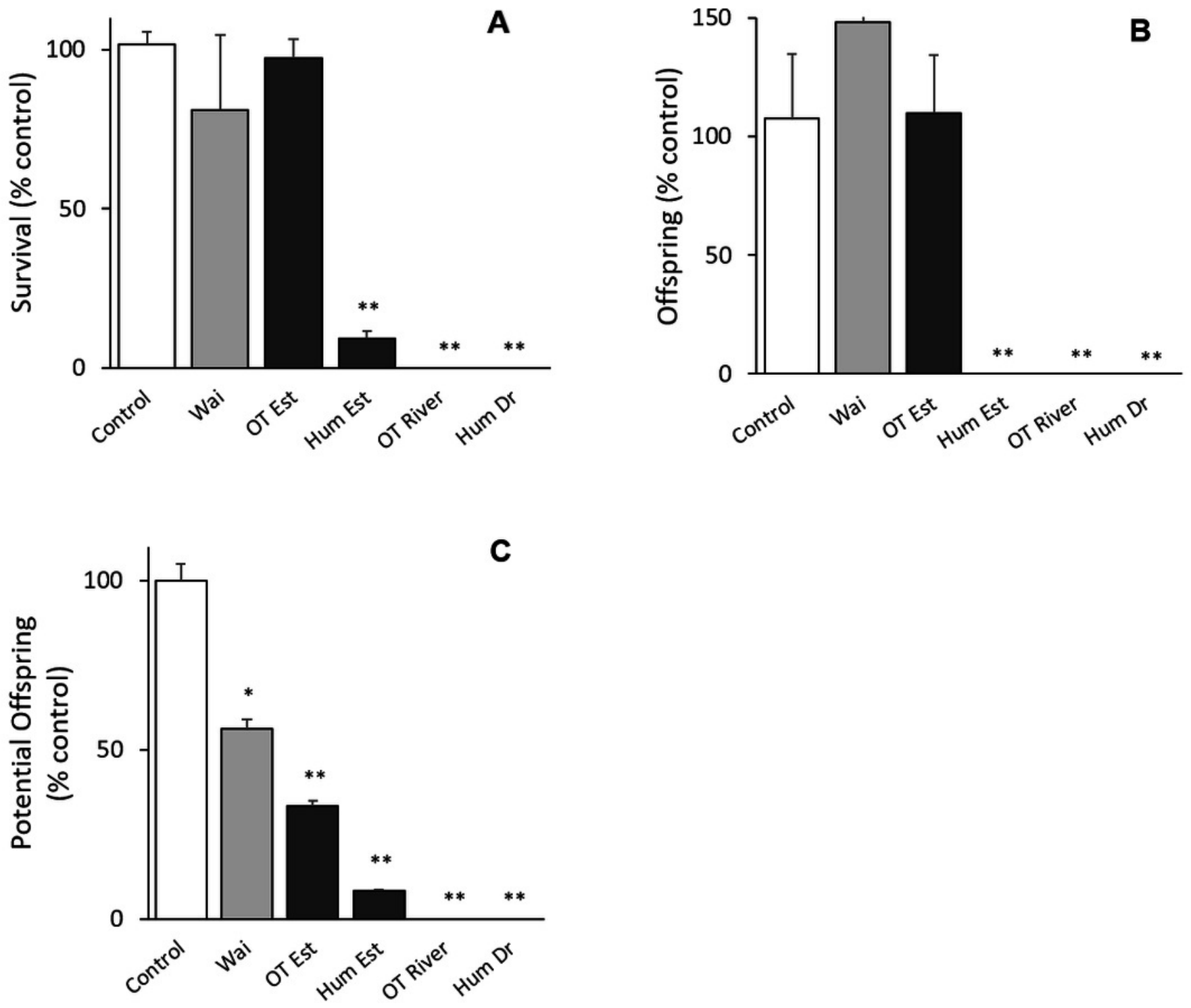
Figure 3

Elutriates acute and chronic results.

(A) Survival and (B) larval development ratio of Gladioferens pectinatus after exposure to elutriates from selected sites at the Ahuriri Estuary, and Waitangi Estuary. Significance levels: '*'p $<0.05,{ }^{\prime * * '} p<0.001$, Dunnett's multiple comparison against the control.
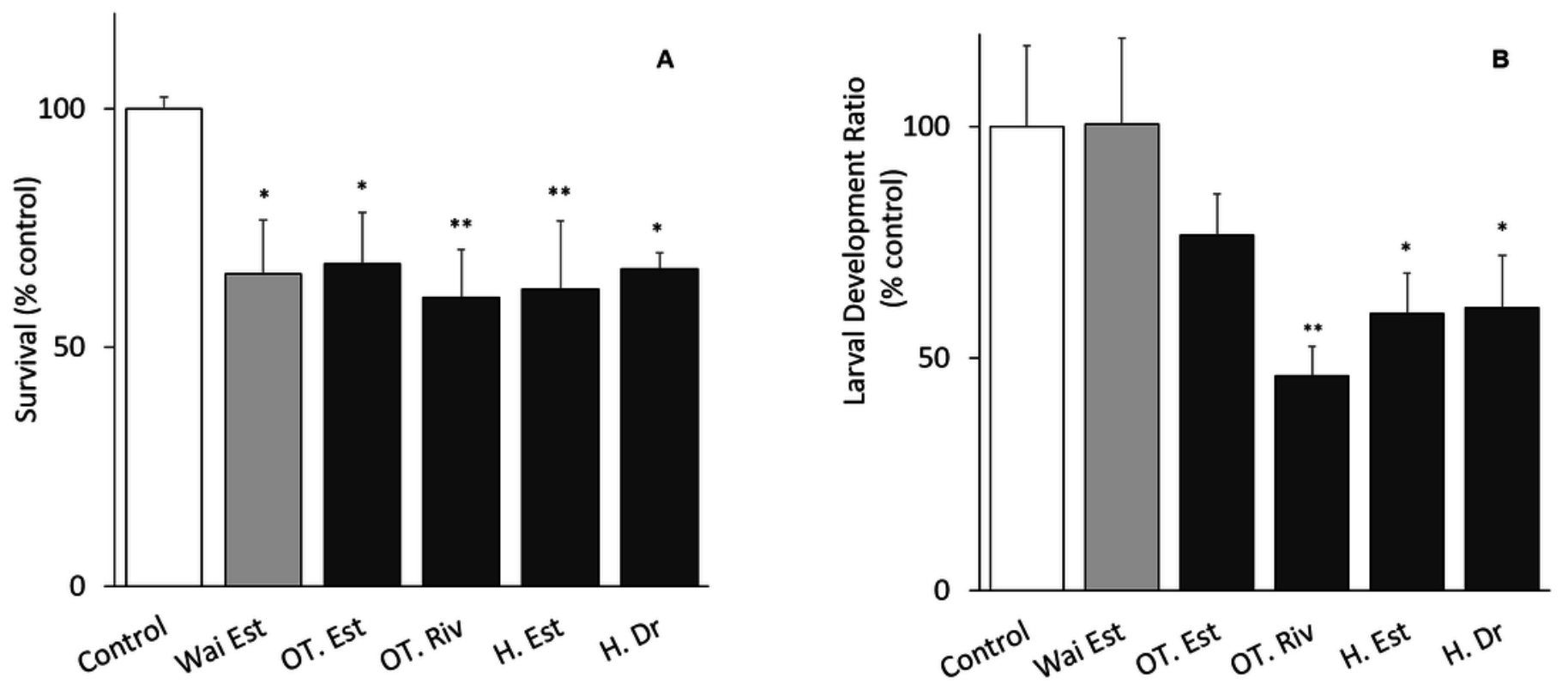
Figure 4

DNA damage on cells isolated from copepods exposed to sediment elutriates.

(A) Tail Moment. (B) Tail Intensity. (CN) Negative control, (CP) Positive control, and elutriates from the (HD) Humber Drain, (HE) Humber Estuary, (OE) Old Tutaekuri Estuary and (OR) Old Tutaekuri Riverbed sediments. * Indicates significance difference from control $(p<0.05)$. Humber drain $(p<0.01)$ and Old Tutaekuri Riverbed $(p<0.001)$.
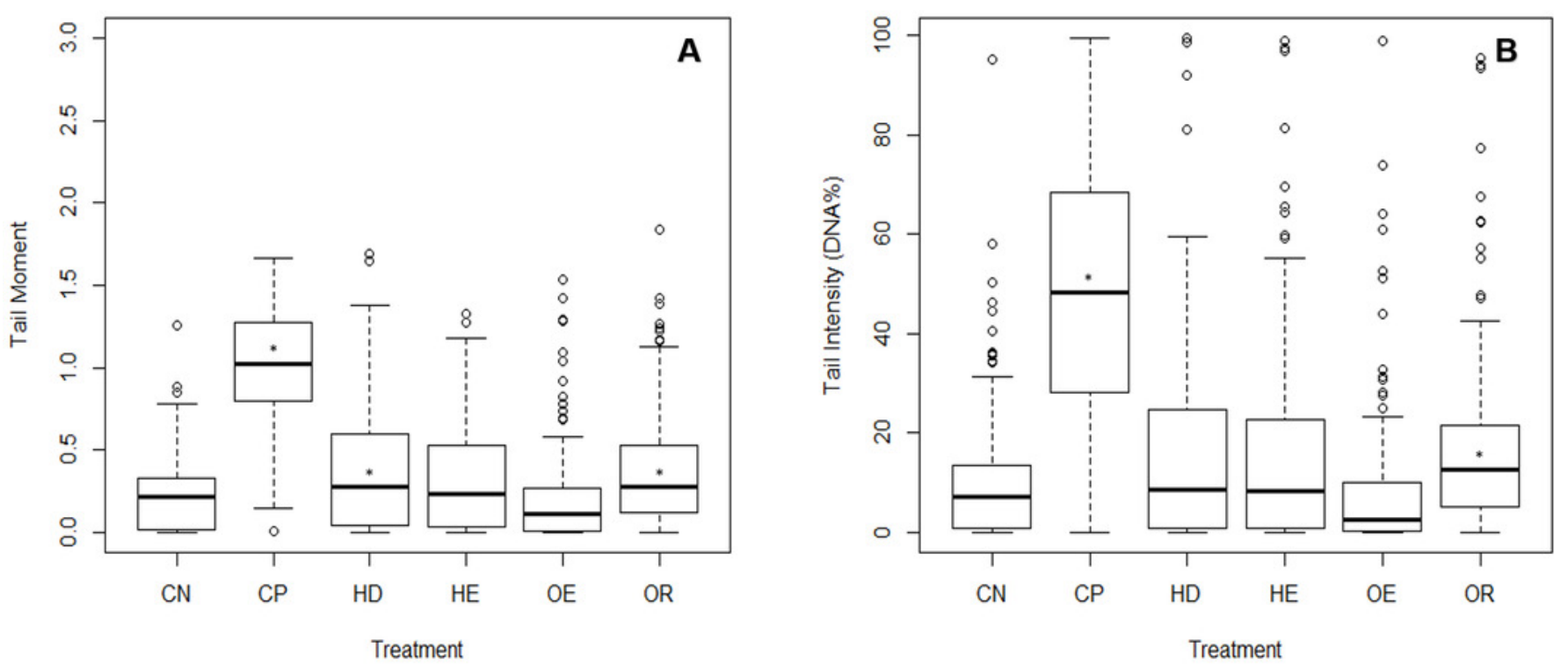


\section{Table $\mathbf{1}$ (on next page)}

Mean concentrations ( $\mathrm{mg} \cdot \mathrm{kg}^{-1} \mathrm{dry}$ weight) of trace metals in sediment samples.

Analytes from the four sites of the Ahuriri Estuary, and from the reference site, Waitangi Estuary. The ANZEEC Interim Sediment Quality Guidelines (ISQG) represent levels above which there is a low probability of biological effects (ISQG-Low) and high probability of biological effect (ISQG High). Analytes above thresholds values are indicated as * for ISQG-low. 


\begin{tabular}{llllll}
\hline & Arsenic & Cadmium & Copper & Lead & Zinc \\
\hline ANZECC ISQG-Low & 20 & 1.5 & 65 & 50 & 200 \\
ANZECC ISQG-High & 70 & 10 & 270 & 220 & 410 \\
Humber Drain & 4.7 & 0.32 & 16.7 & 32 & $310^{*}$ \\
Humber Estuary & 3.7 & 0.018 & 4.7 & 9.9 & 57 \\
Old Tutaekuri Riverbed & 4.7 & 0.127 & 13.9 & 16.1 & $280^{*}$ \\
Old Tutaekuri Estuary & 3 & 0.024 & 4.4 & 7.3 & 47 \\
Waitangi Estuary & 6.4 & 0.079 & 11.9 & 15.3 & 61 \\
\hline
\end{tabular}

1

2 


\section{Table 2 (on next page)}

\section{Sediment physicochemical properties from the five studysites.}

$\mathrm{TOC}=$ Total Organic Carbon; TRP= Total Recoverable Phosphorus; $\mathrm{TN}=$ Total Nitrogen; Sal = Salinity. Values for $\mathrm{pH}$ and redox are the average between results from beginning and end of test. 


\begin{tabular}{|c|c|c|c|c|c|c|c|}
\hline & $\mathrm{pH}$ & $\begin{array}{l}\text { Redox } \\
(\mathrm{mV})\end{array}$ & $\begin{array}{l}\text { Ammonia } \\
\left(\mathrm{mg} \cdot \mathrm{kg}^{-1} \mathrm{dry}\right. \\
\text { weight })\end{array}$ & TOC & $\begin{array}{l}\text { TRP } \\
\left(\mathrm{mg} \cdot \mathrm{kg}^{-1} \mathrm{dry}\right. \\
\text { weight })\end{array}$ & $\begin{array}{l}\mathrm{TN} \\
\left(\mathrm{g} \cdot 100 \mathrm{~g}^{-1} \text { dry }\right. \\
\text { weight })\end{array}$ & $\begin{array}{l}\text { Sal } \\
\text { (ppt) }\end{array}$ \\
\hline Humber Drain & 7.87 & 145 & 2.9 & 2.50 & 1160 & 0.12 & 29.6 \\
\hline Humber Estuary & 7.84 & 228.5 & 4.4 & 0.36 & 360 & 0.05 & 29.6 \\
\hline Old Tutaekuri Riverbed & 7.77 & 109.0 & 22.0 & 0.15 & 340 & $<0.05$ & 29.6 \\
\hline Old Tutaekuri Estuary & 7.87 & 171.4 & 9.0 & 1.06 & 390 & 0.11 & 29.6 \\
\hline Waitangi Estuary & 7.99 & 126.0 & 5.7 & 1.45 & 650 & 0.21 & 29.6 \\
\hline
\end{tabular}

1

2

3

4 


\section{Table 3(on next page)}

\section{Dissolved concentrations $\left(\mu \mathrm{g} \cdot \mathrm{L}^{-1}\right)$ of trace metals from sediment elutriates.}

Analytes obtained from the four study sites at the Ahuriri Estuary, and from the reference site, the Waitangi Estuary. ID= Insufficient data; ND= Not detected. Analytes above the ANZECC guidelines thresholds values are indicated with $*$ for a level of protection of $95 \%$ and above. 


\begin{tabular}{llllll}
\hline & $\begin{array}{c}\text { Arsenic } \\
\left(\mu \mathrm{g} \cdot \mathrm{L}^{-1}\right)\end{array}$ & $\begin{array}{l}\text { Cadmium } \\
\left(\mu \mathrm{g} \cdot \mathrm{L}^{-1}\right)\end{array}$ & $\begin{array}{l}\text { Copper } \\
\left(\mu \mathrm{g} \cdot \mathrm{L}^{-1}\right)\end{array}$ & $\begin{array}{l}\text { Lead } \\
\left(\mu \mathrm{g} \cdot \mathrm{L}^{-1}\right)\end{array}$ & $\begin{array}{c}\text { Zinc } \\
\left(\mu \mathrm{g} \cdot \mathrm{L}^{-1}\right)\end{array}$ \\
\hline ANZECC Guidelines 99\% ${ }^{\mathrm{a}}$ & $\mathrm{ID}$ & 0.7 & 0.3 & 2.2 & 7 \\
ANZECC Guidelines 95\% ${ }^{\mathrm{a}}$ & $\mathrm{ID}$ & 5.5 & 1.3 & 4.4 & 15 \\
Humber Drain & $<4$ & $<0.2$ & $<1$ & $4.1^{*}$ & $75^{*}$ \\
Humber Estuary & $\mathrm{ND}$ & 0.2 & 1 & 1.6 & $33^{*}$ \\
Old Tutaekuri Riverbed & $<4$ & $<0.2$ & $<1$ & $5.3 *$ & $59^{*}$ \\
Old Tutaekuri Estuary & $\mathrm{ND}$ & 0.2 & $2.2^{*}$ & 2.2 & $44^{*}$ \\
Waitangi Estuary & $<4$ & 0.5 & $8.3^{*}$ & 4 & $33^{*}$ \\
\hline
\end{tabular}

1

2 a ANZECC 2000 water quality guidelines trigger values for 99 and $95 \%$ of protection levels for 3 species in marine waters. 